\title{
Regulatory properties of 6-phosphofructokinase and control of glycolysis in boar spermatozoa
}

\author{
G Kamp, H Schmidt, H Stypa, S Feiden, C Mahling and G Wegener \\ Institut für Zoologie, Johannes Gutenberg-Universität, Becherweg 9-11, D-55099 Mainz, Germany \\ Correspondence should be addressed to G Wegener; Email: gwegener@uni-mainz.de
}

\begin{abstract}
Glycolysis is crucial for sperm functions (motility and fertilization), but how this pathway is regulated in spermatozoa is not clear. This prompted to study the location and the regulatory properties of 6-phosphofructokinase (PFK, EC 2.7.1.11), the most important element for control of glycolytic flux. Unlike some other glycolytic enzymes, PFK showed no tight binding to sperm structures. It could readily be extracted from ejaculated boar spermatozoa by sonication and was then chromatographically purified. At physiological pH, the enzyme was allosterically inhibited by near-physiological concentrations of its co-substrate ATP, which induced co-operativity, i.e. reduced the affinity for the substrate fructose 6-phosphate. Inhibition by ATP was reinforced by citrate and $\mathrm{H}^{+}$. Above $\mathrm{pH} \mathrm{8,} \mathrm{PFK} \mathrm{lost} \mathrm{all} \mathrm{its} \mathrm{regulatory} \mathrm{properties} \mathrm{and} \mathrm{showed} \mathrm{maximum} \mathrm{activity.} \mathrm{However,} \mathrm{in} \mathrm{the} \mathrm{physiological}$ pH range, PFK activity was very sensitive to small changes in effectors. At near-physiological substrate concentrations, PFK activity requires activators (de-inhibitors) of which the combination of $A M P$ and fructose 2,6-bisphosphate $\left(F 2,6 P_{2}\right)$ was most efficient as a result of synergistic effects. The kinetics of PFK suggest AMP, $F 2,6 P_{2}, \mathrm{H}^{+}$, and citrate as allosteric effectors controlling PFK activity in boar spermatozoa. Using immunogold labeling, PFK was localized in the mid-piece and principal piece of the flagellum as well as in the acrosomal area at the top of the head and in the cytoplasmic droplets released from the mid-piece after ejaculation.
\end{abstract}

Reproduction (2007) 133 29-40

\section{Introduction}

Glycolysis is important for fertility of mammalian spermatozoa. Spermatozoa from rat epididymis proved unable to fertilize eggs in vitro if either glucose was omitted from (Niwa \& Iritani 1978) or substances blocking glycolysis were added to the medium (Bone et al. 2000). Fertilization seems to require hyperactivity, a special form of sperm motility, which (unlike progressive motility) can only be observed if glycolysis is not hampered (Fraser \& Quinn 1981). Hyperactivity, which is characterized by the flagellum beating vigorously with a high amplitude like in a whiplash, is thought to generate mechanical thrust for penetration of the zona pellucida surrounding the egg (see Bedford 1998, Ho \& Suarez 2001). The importance of glycolysis for fertility in boar sperm has also been stressed by Marin et al. (2003).

In vivo, hyperactivity is apparently induced in the female genital tract when spermatozoa undergo complex structural and metabolic changes that are collectively termed capacitation. However, how glycolysis, hyperactivity, and sperm fertility are causally and functionally linked is not clear. This again is, at least in part, due to the fact that it is not fully understood how glycolysis in spermatozoa is organized and regulated.

Spermatozoa are highly specialized for delivering the male genome to the egg, and this is reflected in their shape and structures. Sperm cells are elongated and clearly divided into head and tail (flagellum), the latter bringing about motility. Since spermatozoa face fierce competition on their way to the oocyte, efficient motility is crucial for reproductive success. Adaptations for improved motility are obvious as maturating spermatozoa shed structures for non-essential cellular functions, such as protein synthesis, glycogen storage etc. (for review see Mann \& Lutwak-Mann 1981). On the other hand, motility requires efficient energy metabolism, yet how spermatozoa are metabolically adapted to their function is less obvious. The prime function of sperm metabolism is to provide the flagellar motor with free energy by hydrolysis of ATP. ATP is most efficiently produced aerobically which requires mitochondria. These rather bulky organelles cannot be distributed along the flagellum because this would cause mechanical problems in the beating flagellum. Mitochondria in mammalian sperm are hence 
concentrated behind the head in the mid-piece of sperm leaving the thrust-producing structures in the principal piece of sperm distant from the mitochondria. Hence, ATP would either have to be transported along the flagellum or produced locally by glycolysis (Kamp et al. 1996, Westhoff \& Kamp 1997, Bunch et al. 1998, Mori et al. 1998, Travis et al. 1998).

The close correlation of glycolysis, hyperactivity, and fertility prompted the question as to how glycolysis is controlled in spermatozoa. In a thorough study, Travis et al. (2001) have recently dismissed hexokinase as a major site of glycolytic control in murine spermatozoa, while Jones \& Connor (2004) have adduced evidence that control must be located between hexokinase and aldolase in boar sperm. These results point to 6-phosphofructokinase (PFK, EC 2.7.1.11) as a likely candidate because in many tissues and cell types this enzyme has been identified as the main regulatory enzyme of glycolysis. PFK catalyzes the highly exergonic reaction: fructose 6-phosphate $(\mathrm{F} 6 \mathrm{P})+\mathrm{ATP} \rightarrow$ fructose 1,6-bisphosphate $\left(\mathrm{F} 1,6 \mathrm{P}_{2}\right)+\mathrm{ADP}$. The activity of PFK is allosterically modulated by a number of effectors (for review see Kemp \& Foe 1983, Krause \& Wegener 1996b, 1996c). The control of PFK activity is based on allosteric inhibition by physiological concentrations of its cosubstrate ATP, which lowers the affinity for its substrate, so that physiological concentrations of F6P are not sufficient for PFK activity. This inhibition is reinforced by $\mathrm{H}^{+}$(low $\mathrm{pH}$ ) and by citrate. PFK can be de-inhibited (activated) by positive effectors, some of which are related directly to the turnover of ATP, so that their concentrations are increased whenever ATP turnover is increased. This would apply to inorganic phosphate $\left(\mathrm{P}_{\mathrm{i}}\right)$, ADP, and AMP, which are part of an intracellular feedback mechanism by which PFK activity can be adjusted to ATP demand (see Krause \& Wegener 1996a, 1996b, 1996c, Wegener 1996, Wegener \& Krause 2002). In contrast to these effectors, the very potent PFK activator fructose 2,6-bisphosphate $\left(\mathrm{F}_{2}, 6 \mathrm{P}_{2}\right)$ has been shown to respond also to extracellular signals, such as hormones or neuromodulators (see Hue \& Rider 1987, Pilkis 1990, Wegener 1996, Wegener \& Krause 2002, Mentel et al. 2003, Almeida et al. 2004). Moreover, $\mathrm{F} 2,6 \mathrm{P}_{2}$ was the most potent activator to overcome the inhibitory effect of citrate in PFK from skeletal muscle (Wegener et al. 1990, Krause \& Wegener 1996b, 1996c; see also Tornheim 1985). This is potentially relevant in sperm because seminal plasma from mammals contains citrate at unusually high concentrations $(11.7 \mathrm{mmol} / \mathrm{l}$ in case of boar, Kamp \& Lauterwein 1995).

Given the important role of glycolysis for sperm function, little is known about the regulatory properties of PFK from spermatozoa. PFK of monkey spermatozoa was shown to be inhibited by ATP and citrate, whereas $P_{i}$ and AMP were activators (Hoskins \& Stephens 1969). $\mathrm{F} 2,6 \mathrm{P}_{2}$ has been demonstrated to activate PFK from rat spermatids (Nakamura et al. 1984) and from bull epididymal spermatozoa (Philippe et al. 1986), but not yet in PFK from sperm cells that are physiologically motile. Spermatozoa become motile after ejaculation when they are mixed with fluids from accessorial glands that are rich in citrate. Possible effects of citrate on PFK activity have not been considered in the two latter papers, while $\mathrm{F} 2,6 \mathrm{P}_{2}$ could not take into account before its discovery in 1980. In a recent report on sperm glycolysis, Jones \& Connor (2004) focused on pH, and did not find any effects of ATP and citrate on PFK activity.

We set out to analyze the kinetic and the regulatory properties of PFK from ejaculated boar spermatozoa and also the intracellular location of the enzyme using immunogold labeling. An important role for PFK in regulating sperm glycolysis is proposed and possible mechanisms of control at this step will be discussed.

\section{Materials and Methods}

\section{Chemicals}

All chemicals were of the highest available purity. Biochemicals and enzymes were purchased from Roche, immunochemicals from Sigma, antibodies from DPC Biermann (Diagnostic Products Corp. Biermann, Bad Nauheim, Germany), Q-Sepharose was from Amersham Biosciences, and membranes for ultrafiltration from Millipore (Schwalbach, Germany). All other chemicals were obtained from Merck.

\section{Purification of PFK from boar spermatozoa}

Semen from fertile boars was collected manually, using a dummy sow, and was provided by the breeders association GFS-Ascheberg (Genossenschaft zur Förderung der Schweinehaltung e.G., Ascheberg, Germany). The ejaculates were transported to the lab at a temperature between 15 and $18{ }^{\circ} \mathrm{C}$, which renders the spermatozoa immotile. All experimental steps were carried out at $4{ }^{\circ} \mathrm{C}$ if not mentioned otherwise. Semen diluted with the same volume of Beltsville thawing solution (BTS (pH 7.3) comprising $205 \mathrm{mmol} / /$ glucose, $20.6 \mathrm{mmol} / \mathrm{l} \mathrm{Na}_{3}$ citrate, $15 \mathrm{mmol} / \mathrm{l} \mathrm{NaHCO}_{3}$, $3.4 \mathrm{mmol} / \mathrm{l}$ EDTA, $10 \mathrm{mmol} / \mathrm{l} \mathrm{KCl}, 0.6 \mathrm{~g} / \mathrm{l}$ penicillin, and $1 \mathrm{~g} / \mathrm{l}$ streptomycin) was centrifuged at $10000 \mathrm{~g}$ for $15 \mathrm{~min}$, the supernatant discarded and the sedimented spermatozoa stored at $-20^{\circ} \mathrm{C}$ until use. Approximately, $75 \mathrm{~g}$ frozen spermatozoa were diluted with $75 \mathrm{ml}$ of $\mathrm{P}_{\mathrm{i}^{-}}$ buffer ( $\mathrm{pH} 7.3$ ) comprising $10 \mathrm{mmol} / \mathrm{l} \mathrm{NaP}, 1 \mathrm{mmol} / \mathrm{l}$ EDTA, $1 \mathrm{mmol} / \mathrm{l}$ dithiothreitol, and $0.2 \mathrm{ml}$ stock solution of $10 \mathrm{mmol} / /$ phenyl-methylsulforylfluoride dissolved in isopropanol. The sperm suspension was homogenized using a Sonifier (Branson Sonic Power Company, Diezenbach, Germany) with maximum power output for $2 \times 60 \mathrm{~s}$ at $0{ }^{\circ} \mathrm{C}$. After centrifugation of the homogenate $(27000 \mathrm{~g}, 10 \mathrm{~min})$, the supernatant (S1) was 
collected and the sediment resuspended with $75 \mathrm{ml} \mathrm{P}_{\mathrm{i}^{-}}$ buffer and centrifuged again. The resulting supernatant S2 was combined with S1 for chromatography on Q-sepharose. PFK was thus readily and almost completely extracted from boar sperm and the activity under optimum assay conditions (see below) accounted for about $0.5 \mathrm{U} / \mathrm{g}$ frozen spermatozoa.

Q-Sepharose Fast Flow (Amersham, $32 \mathrm{ml}$ in a column) was equilibrated with $\mathrm{P}_{\mathrm{i}}$-buffer. Sperm extract $(\mathrm{S} 1+\mathrm{S} 2)$ was pumped onto the column at a flow rate of $2 \mathrm{ml} / \mathrm{min}$. The column was washed with $50 \mathrm{ml}$ of $10 \mathrm{mmol} / \mathrm{l} \mathrm{P}_{\mathrm{i}}$-buffer, then with $200 \mathrm{ml}$ in which $\mathrm{P}_{\mathrm{i}}$ was increased to $50 \mathrm{mmol} / \mathrm{l}$ (see Fig. 1). PFK was eluted using a gradient from 50 to $250 \mathrm{mmol} / \mathrm{l} \mathrm{P}_{\mathrm{i}}$, and fractions of $5 \mathrm{ml}$ were collected. A small fraction of PFK activity had been washed from the column with $50 \mathrm{mmol} / \mathrm{l} \mathrm{P}_{\mathrm{i}}$. On rechromatography (not shown), this fraction was indiscernible from the bulk of PFK.

Fractions containing PFK activity were combined and concentrated to about $10 \mathrm{ml}$ by ultrafiltration in an Amicon ultrafiltration cell with $100 \mathrm{kDa}$ permeation limit (Amicon Diaflo YF 100, Millipore, Eschborn) at 3 bar. The preparation was further concentrated to about $1 \mathrm{ml}$ by centrifugation in a Centricon 100 tube (Millipore), then stabilized with glycerol 1:2 (v/v) and fructose 6-phosphate (F6P, $1 \mathrm{mmol} / \mathrm{l}$ final concentration) and stored at $-20{ }^{\circ} \mathrm{C}$ with no loss of activity and allosteric properties (see Results). Enzymes that could interfere with kinetic measurements had only minor activities (adenylate kinase (AK) $<2 \%$ and lactate dehydrogenase $<1 \%$ of PFK activity).

\section{Assay of phosphofructokinase activity}

PFK (EC 2.7.1.11) activity was measured spectrophotometrically at $340 \mathrm{~nm}$ and $25^{\circ} \mathrm{C}$ in a fructose 1,6-bisphosphate-linked assay in a Zeiss PM6 using

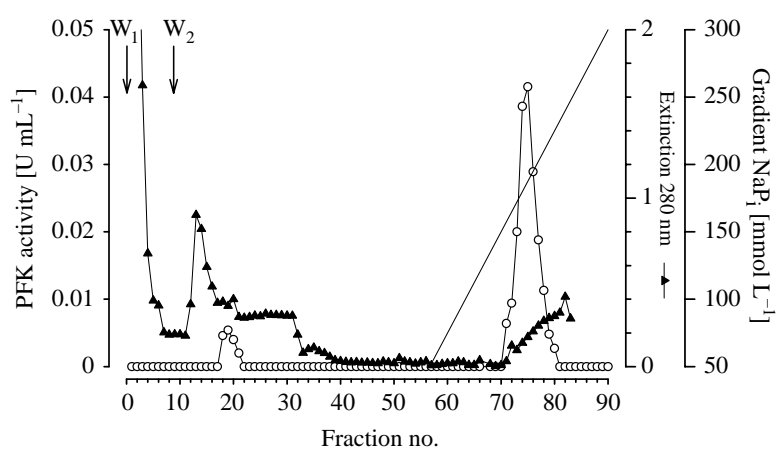

Figure 1 Chromatography of boar sperm PFK on Q-sepharose. Boar sperm extract was applied to a Q-sepharose column in $10 \mathrm{mmol} / \mathrm{l} \mathrm{P}_{\mathrm{i}}$-buffer. The column was washed twice, first with $50 \mathrm{ml}$ of $10 \mathrm{mmol} / / \mathrm{P} \mathrm{P}_{\mathrm{i}}$-buffer $\left(W_{1}\right)$, then with $200 \mathrm{ml}$ of $50 \mathrm{mmol} / \mathrm{l} \mathrm{P}_{\mathrm{i}}$-buffer $\left(W_{2}\right.$; see Materials and Methods). PFK activity (- $\left.O_{-}\right)$was eluted with a linear phosphate gradient (50-300 mmol// $\mathrm{P}_{\mathrm{i}}$-buffer) and appeared in a narrow peak at about $175 \mathrm{mmol} / / \mathrm{l}$ phosphate (for details see text). The bulk of protein (- $\mathbf{\Lambda}-$ ) did not bind to Q-sepharose. Fraction volume was $5 \mathrm{ml}$.
$\mathrm{NADH}+\mathrm{H}^{+}$as indicator. Enzyme activities are given as international units $(1 \mathrm{U}=1 \mu \mathrm{mol}$ substrate transformed per $\min$ at $25^{\circ} \mathrm{C}$ ). The routine assay for PFK was performed at $\mathrm{pH} 7.6$ and comprised $50 \mathrm{mmol} / \mathrm{l}$ triethanolamine buffer (TRAP), $50 \mathrm{mmol} / \mathrm{I} \mathrm{KCl}, 2 \mathrm{mmol} / \mathrm{I}$ $\mathrm{MgCl}_{2}, 10 \mathrm{mmol} / \mathrm{l} \mathrm{NaP}, 1 \mathrm{mmol} / \mathrm{l}$ AMP, $7 \mathrm{mmol} / \mathrm{I}$ glucose 6-phosphate, $2 \mathrm{mmol} / \mathrm{l}$ fructose 6-phosphate (F6P), $0.2 \mathrm{mmol} / \mathrm{l} \mathrm{NADH}+\mathrm{H}^{+}, 2 \mathrm{mmol} / \mathrm{l} \mathrm{MgATP}$, $1.8 \mathrm{U} / \mathrm{ml}$ aldolase (EC 4.1.2.13), $13.6 \mathrm{U} / \mathrm{ml}$ glycerol 3-phosphate dehydrogenase (EC 1.1.1.8), $20 \mathrm{U} / \mathrm{ml}$ triosephosphate isomerase (TIM, EC 5.3.1.1), $2.8 \mathrm{U} / \mathrm{ml}$ phosphoglucose isomerase (EC 5.3.1.9). Optimum activity $\left(V_{\text {opt }}\right)$ was measured at $1 \mathrm{mmol} / \mathrm{l} \mathrm{MgATP}$ and with $1 \mu \mathrm{mol} / \mathrm{l}$ fructose 2,6-bisphosphate $\left(\mathrm{F} 2,6 \mathrm{P}_{2}\right)$ present. The auxiliary enzymes were extensively dialyzed against $250 \mathrm{mmol} / \mathrm{l}$ TRAP $(\mathrm{pH}$ 7.6) to remove $\left(\mathrm{NH}_{4}\right)_{2} \mathrm{SO}_{4}$.

Kinetic measurements of PFK under more physiological conditions were performed as follows: $\mathrm{pH}$ was 7.3 (if not mentioned otherwise in Results), MgATP $4 \mathrm{mmol} / \mathrm{l}$, F6P $0.5 \mathrm{mmol} / \mathrm{l}, \mathrm{P}_{\mathrm{i}} 4 \mathrm{mmol} / \mathrm{l}$, and other compounds as given in Results. Assays were always started with PFK in order to avoid inactivation of PFK due to dilution. In all assays without AMP, traces of ADP and AMP were converted to ATP by an AMP-depleting and ATPregenerating system (cf. Wegener et al. 1987) comprising $5 \mathrm{mmol} / \mathrm{l}$ phosphocreatine, $2.6 \mathrm{mU} / \mathrm{ml}$ creatine kinase (EC 2.7.3.2), and 1.4 U/ml AK (EC 2.7.4.3). Unlike $V_{\text {opt }}$ which indicates the maximum catalytic capacity of PFK under optimal assay conditions, $V_{\max }$ gives the maximum activity that is reached in a series of related measurements in which one or more parameters are varied. The affinities of PFK for its substrates, activators, or inhibitors are indicated by $S_{0.5^{-}}, A_{0.5^{-}}$, and $I_{0.5^{-}}$values respectively which denote the concentrations of ligands at which the effects are half maximum. In the case of Michaelis-Menten kinetics, the $S_{0.5}$ is identical with the Michaelis constant $K_{\mathrm{m}}$. Most of the kinetic tests were performed using PFK preparations of $V_{\text {opt }}$ about $8.5 \mathrm{U} /$ $\mathrm{ml}$. All assays were performed under conditions such that PFK activity was the limiting factor (as indicated by the proportionality of PFK amount and activity). PFK activities between 1 and $20 \mathrm{mU}$ were added per individual assay reaching a constant reaction rate within about $20 \mathrm{~s}$. All figures show representative curves from at least three experiments.

\section{Electrophoresis and immunoblotting}

SDS-PAGE was carried out according to Laemmli (1970). Sperm extract and PFK samples were incubated in buffer (0.25 mol// Tris/HCl (pH 6.8), 20\% 2-mercaptoethanol, $8 \%$ SDS, $40 \%$ glycerol, $0.02 \%$ bromophenol blue) at $95{ }^{\circ} \mathrm{C}$ for $5 \mathrm{~min}$. The samples were put onto the gels $(4 \%$ stacking gel and $10 \%$ running gel) and run at $10{ }^{\circ} \mathrm{C}$, for $30 \mathrm{~min}$ at $70 \mathrm{~V}$, then for $90 \mathrm{~min}$ at $90 \mathrm{~V}$. 
Using a semi-dry method (Kyhse-Andersen 1984), proteins were blotted from the gels onto nitrocellulose membranes at $130 \mathrm{~mA}$ for $60 \mathrm{~min}$. The membranes were washed four times with $\mathrm{P}_{\mathrm{i}}$-buffered saline (PBS: $139 \mathrm{mmol} / \mathrm{I} \mathrm{NaCl}, 3.6 \mathrm{mmol} / \mathrm{l} \mathrm{KH}_{2} \mathrm{PO}_{4}, 12 \mathrm{mmol} / \mathrm{I}$ $\mathrm{Na}_{2} \mathrm{HPO}_{4} ; \mathrm{pH} 7.3$ ) to remove SDS. Non-specific binding sites on the membrane were blocked with BSA ( $3 \%$ BSA in PBS, 60 min). The membrane was washed four times with BSA-free PBS and overnight incubated with goat antibodies (raised against rabbit muscle PFK) diluted 2000 -fold with PBS. The membranes were rinsed in PBS and incubated at $20^{\circ} \mathrm{C}$ for $1 \mathrm{~h}$ with an anti-goat IgG that was conjugated with horseradish peroxidase (dilution 1:16 000 in PBS with 1\% BSA). The membrane was again rinsed in PBS, then stained with 3,3diaminobenzidine.

\section{Electron microscopy and immunogold labeling}

Immunoelectron microscopy was performed according to the postembedding procedure (see Westhoff \& Kamp 1997). Thin sections $(80-90 \mathrm{~nm})$ of embedded semen samples were collected on polyvinyl formal (Formvar)coated nickel grids, etched for 2 min with saturated sodium periodate and further processed for immunogold labeling as described by Wolfrum \& Schmitt (2000). The goat anti-rabbit muscle PFK, diluted 500 -fold, was added and the grids were incubated at $20^{\circ} \mathrm{C}$ for $1 \mathrm{~h}$. After washing (four times with $100 \mathrm{ml}$ PBS containing $1 \%$ BSA), anti-goat $\operatorname{lgG}$, conjugated with $10 \mathrm{~nm}$ gold particles (Sigma G7402) and diluted in the ratio of 1:40 or 1:50, was added to the specimens for $1 \mathrm{~h}\left(20^{\circ} \mathrm{C}\right)$. Sections were counterstained for 10-20 min with 2\% aqueous uranyl acetate and subsequently for $2 \mathrm{~min}$ with lead citrate according to Hanaichi et al. (1986). Immunogold labeling was analyzed by electron microscope (FEI Tecnai 12 Biotwin; 5600 KA Eindhoven, The Netherlands).

For an additional control, anti-rabbit muscle PFK were preincubated with purified PFK from rabbit muscle in order to eliminate the antibodies directed against PFK: $210 \mu \mathrm{g}$ rabbit muscle PFK per $\mu \mathrm{g}$ anti-rabbit muscle PFK were incubated under gentle agitation at $30{ }^{\circ} \mathrm{C}$ for $1 \mathrm{~h}$ and for further $22 \mathrm{~h}$ at $4{ }^{\circ} \mathrm{C}$. The immune complexes were sedimented $\left(10000 \mathrm{~g} ; 15 \mathrm{~min} ; 4^{\circ} \mathrm{C}\right)$ and the supernatant was used as in the immunogold labeling experiment.

\section{Results}

\section{Extraction and purification of boar sperm PFK}

Phosphofructokinase was readily extracted from boar spermatozoa by sonication in phosphate buffer $(>90 \%$ of total activity). The activity under optimum conditions $\left(V_{\text {opt }}\right)$ showed individual variation, but was usually $>0.5 \mathrm{U} / \mathrm{g}$ (wet) frozen weight corresponding to
$>0.1 \mathrm{mU}$ per $10^{6}$ spermatozoa. PFK appeared homogeneous upon chromatography (see Fig. 1). The enzyme preparation was sufficiently pure for kinetic studies (see Materials and Methods).

\section{Boar sperm PFK is inhibited by physiological concentrations of ATP}

In the absence of activators (with the exception of inorganic phosphate, $\mathrm{P}_{\mathrm{i}}$, which was present at $4 \mathrm{mmol} / \mathrm{l}$ in these and all following PFK assays), the activity of PFK plotted against the concentration of its co-substrate ATP (v/(ATP)-curve) resulted in optimum curves, i.e. PFK reached peak activity at rather low concentrations of ATP and was strongly inhibited by ATP in the physiological concentration range (see Fig. 2). This indicates that ATP at physiological concentrations is a potent inhibitor of sperm PFK. The shape of the curves was dependent on the concentration of the substrate F6P. At $0.5 \mathrm{mmol} / \mathrm{I} \mathrm{F6P,} \mathrm{the} \mathrm{v} /(\mathrm{ATP})$-curve formed an early and narrow peak, which became broadened when F6P was increased to $2 \mathrm{mmol} / \mathrm{l}$, indicating that the inhibitory effect of ATP is attenuated by higher concentrations of F6P (for details, see Fig. 2). It is notable that PFK activity is completely blocked by near-physiological concentrations of ATP (i.e. $>2 \mathrm{mmol} / \mathrm{l}$; see Discussion) if the substrate F6P is in the physiological concentration range, i.e. $\leq 0.5 \mathrm{mmol} / \mathrm{l}$.

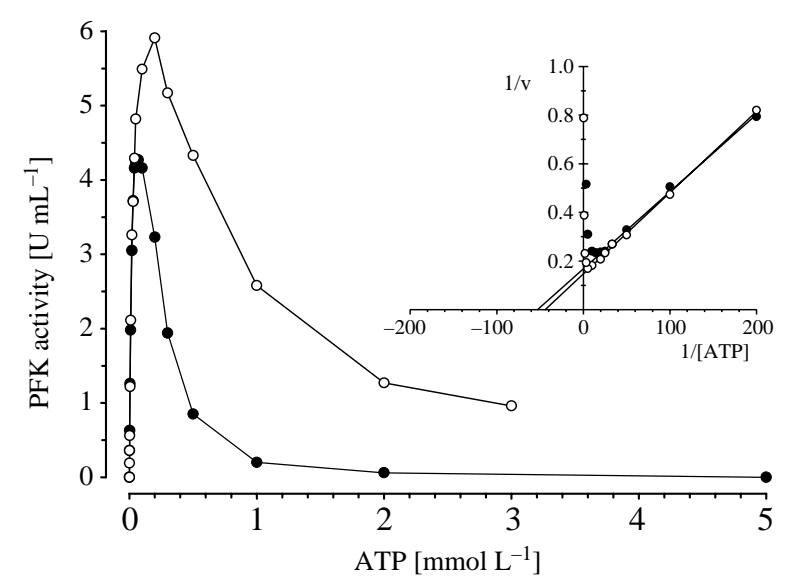

Figure 2 Inhibition of PFK from boar sperm by near-physiological concentrations of ATP at $\mathrm{pH}$ 7.3. PFK has high affinity for ATP, and Lineweaver-Burk plots (insert) show that at low ATP concentrations the v/(ATP)-curve follows Michaelis-Menten kinetics, whereas at higher concentrations ATP acts as a potent inhibitor. Increasing F6P concentration attenuates inhibition by ATP, but has little effect on the affinity of PFK for ATP. At $0.5 \mathrm{mmol} / \mathrm{F}$ FPP (values at $2.0 \mathrm{mmol} / \mathrm{l} \mathrm{F6P} \mathrm{are}$ given in parentheses) the $K_{\mathrm{m}}$ was $0.019 \mathrm{mmol} / \mathrm{I}$ ATP $(0.022 \mathrm{mmol} / \mathrm{l}$ ATP), $V_{\max }$ from Lineweaver-Burk plots was $6.0 \mathrm{U} / \mathrm{ml}(6.8 \mathrm{U} / \mathrm{ml})$, the actual $V_{\max }$ was $4.3 \mathrm{U} / \mathrm{ml}$, reached at about $0.07 \mathrm{mmol} / \mathrm{l}$ ATP $(6.0 \mathrm{U} / \mathrm{ml}$, reached at $0.2 \mathrm{mmol} / \mathrm{l}$ ATP), and $50 \%$ inhibition was seen at $0.3 \mathrm{mmol} / \mathrm{l}$ ATP $(0.9 \mathrm{mmol} / \mathrm{l}$ ATP $)$. The assays contained either

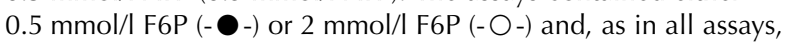
$4 \mathrm{mmol} / \mathrm{l} \mathrm{P}_{\mathrm{i}}$. An ATP-regenerating system was used to remove from the assays traces of AMP and ADP (see Materials and Methods). 


\section{Effects of the activators $A M P$ and $F 2,6 P_{2}$ on PFK activity at varied FGP concentrations}

Unlike ATP, the substrate F6P had no capacity for inhibiting sperm PFK. But the curves of PFK activity versus F6P concentration (v/(S)-curves) differed greatly, depending on whether or not activators were present in the assays (Fig. 3). At $4 \mathrm{mmol} / \mathrm{l} \mathrm{MgATP}$, the $\mathrm{v} /(\mathrm{S})$-curve was sigmoid if no other effectors were present. This indicates co-operativity with respect to substrate binding and low substrate affinity in the physiological concentration range (see Fig. 3 and legend). $\mathrm{F}_{2}, 6 \mathrm{P}_{2}$ proved a potent activator of PFK as $1 \mu \mathrm{mol} / \mathrm{l}$ was sufficient to markedly increase substrate affinity and reduce the sigmoidity of the $\mathrm{v} /(\mathrm{S})$-curve (the Hill coefficient $n_{\mathrm{H}}$ decreased from about 4 to 2.4). AMP also increased the affinity and reduced the co-operativity (Hill coefficient, $n_{\mathrm{H}}=1.5$ ), while both activators acting together resulted in high affinity of PFK for F6P and loss of co-operativity with respect to F6P binding $\left(n_{\mathrm{H}}=0.9\right)$. In summary, the kinetics at near-physiological ATP concentration show PFK from boar spermatozoa to be an allosterically regulated enzyme of the K-type as its substrate affinity could be modulated over a large range $\left(\mathrm{S}_{0.5}\right.$ between 0.1 and $3.2 \mathrm{mmol} / \mathrm{l}$ ), while the $V_{\max }$ values did not decrease below $65 \%$ of $V_{\text {opt }}$ (Fig. 3).

\section{Effects of varied concentrations of citrate, AMP, and $F 2,6 P_{2}$ on PFK activity}

Citrate, which was always added as Mg-citrate because of its capacity to chelate divalent cations, proved to be a very potent inhibitor of sperm PFK. In assays at $\mathrm{pH} 7.3$

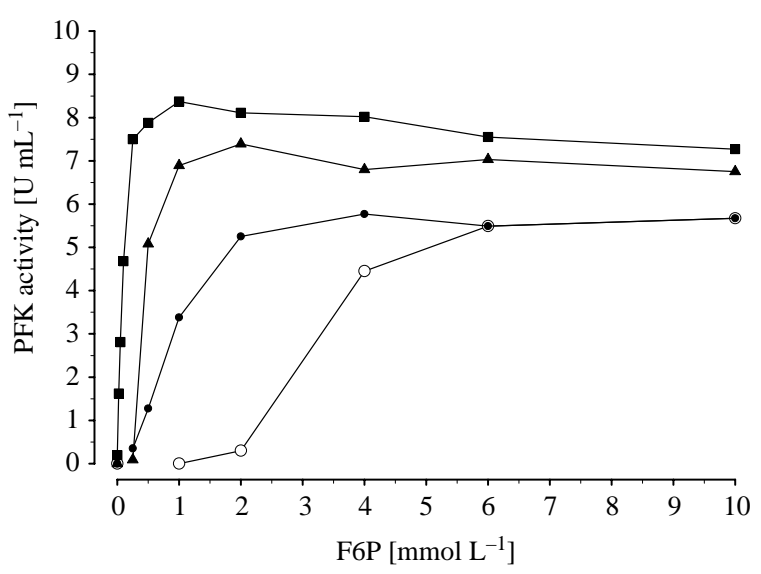

Figure 3 Effects of the concentration of F6P on the activity of PFK from boar sperm in the absence and the presence of AMP and $F 2,6 \mathrm{P}_{2}$. Both AMP and $F 2,6 \mathrm{P}_{2}$ activated PFK by increasing its affinity for the substrate F6P as indicated by the substrate concentrations $S_{0.5}$ required for $V_{\max } / 2$, which were: $S_{0.5}=3.2 \mathrm{mmol} / \mathrm{F} 6 \mathrm{P}$ in the absence of activators

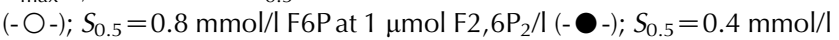
F6P at $100 \mu \mathrm{mol} / / \mathrm{AMP}(-\boldsymbol{\Lambda}-) ; S_{0.5}=0.1 \mathrm{mmol} / \mathrm{I} \mathrm{F} 6 \mathrm{P}$ with both $1 \mu \mathrm{mol} / \mathrm{l}$ $\mathrm{F} 2,6 \mathrm{P}_{2}$ and $100 \mu \mathrm{mol} / \mathrm{l}$ AMP present (- $\mathbf{-}$-). The assays were performed at $\mathrm{pH} 7.3$ and $4 \mathrm{mmol} / \mathrm{I}$ ATP. They contained an AMP-depleting, ATPregenerating system (see Materials and Methods) if no AMP was added. containing $0.5 \mathrm{mmol} / \mathrm{l}$ F6P, $4 \mathrm{mmol} / \mathrm{l}$ ATP, $0.1 \mathrm{mmol} / \mathrm{I}$ AMP and $4 \mathrm{mmol} / \mathrm{l} \mathrm{P}_{\mathrm{i}}$, as little as $0.05 \mathrm{mmol} / \mathrm{l}$ citrate reduced the $V_{\max }$ of PFK activity by more than $80 \%$, and $0.25 \mathrm{mmol} / \mathrm{I}$ citrate fully eliminated the activating effect of $0.1 \mathrm{mmol} / \mathrm{I}$ AMP (Fig. 4). Combined, AMP plus F2, $6 \mathrm{P}_{2}$ (at $1 \mu \mathrm{mol} / \mathrm{l}$ ) could attenuate inhibition by citrate, yet 50 and $94 \%$ inhibition of PFK activity were still brought about by $0.5 \mathrm{mmol} / \mathrm{l}$ and $2 \mathrm{mmol} / \mathrm{l}$ citrate respectively. Increasing $\mathrm{F} 2,6 \mathrm{P}_{2}$ to $5 \mu \mathrm{mol} / \mathrm{l}$ (with no AMP added) markedly counteracted the inhibition by citrate $(50 \%$ inhibition at $I_{0.5}=3 \mathrm{mmol} / \mathrm{l}$ citrate). The additional presence of $0.5 \mathrm{mmol} / \mathrm{l}$ AMP further reduced the inhibitory effect of citrate, especially at concentrations $>2 \mathrm{mmol} / \mathrm{l}$ citrate (Fig. 4).

The very potent inhibitory effect of citrate and its capacity of counteracting the activator AMP and to a lesser extent, also $\mathrm{F} 2,6 \mathrm{P}_{2}$ were also evident when the concentrations of AMP and $\mathrm{F} 2,6 \mathrm{P}_{2}$ were varied at constant citrate levels. At $0.5 \mathrm{mmol} / \mathrm{I} \mathrm{F} 6 \mathrm{P}$ and $4 \mathrm{mmol} / \mathrm{I}$ ATP, $0.5 \mathrm{mmol} / \mathrm{l}$ citrate fully eliminated the activating effect of AMP (Fig. 5). In the absence of citrate and in the presence of $1 \mu \mathrm{mol} / / \mathrm{F} 2,6 \mathrm{P}_{2}$, as little as $10 \mu \mathrm{mol} / \mathrm{I} \mathrm{AMP}$ fully activated sperm PFK, whereas under otherwise identical conditions almost $200 \mu \mathrm{mol} / \mathrm{l}$ AMP where necessary for $V_{\max } / 2$ if $0.5 \mathrm{mmol} / \mathrm{l}$ citrate was present in the assays (Fig. 5).

Citrate (at $0.5 \mathrm{mmol} / \mathrm{l}$ ) reduced markedly, but not fully, the activating effect of $F 2,6 \mathrm{P}_{2}$ (in the absence of AMP), increasing the $A_{0.5}$ value (yielding $50 \%$ activation) from 0.4 to $10 \mu \mathrm{mol} / \mathrm{l}$ F2,6 $\mathrm{P}_{2}$ (Fig. 6). However, with AMP present (at $100 \mu \mathrm{mol} / \mathrm{l}$ ), $\mathrm{F} 2,6 \mathrm{P}_{2}$ proved a very potent activator in a narrow concentration range as $\mathrm{F}_{2}, 6 \mathrm{P}_{2}>$ $2 \mu \mathrm{mol} / \mathrm{l}$ almost fully reverted inhibition of PFK by $0.5 \mathrm{mmol} / \mathrm{l}$ citrate $\left(A_{0.5}=1 \mu \mathrm{mol} / \mathrm{l} \quad \mathrm{F} 2,6 \mathrm{P}_{2}\right)$. Hence,

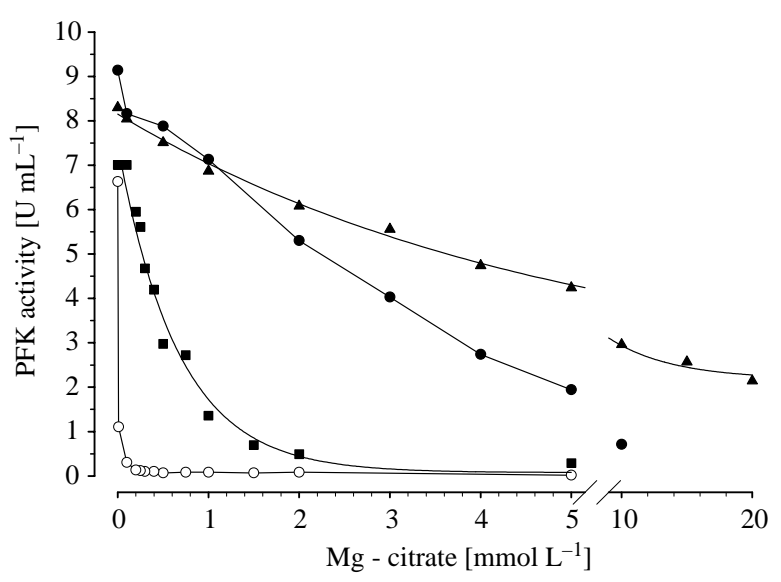

Figure 4 Inhibition of boar sperm PFK by citrate. PFK activity was completely inhibited by citrate $(>0.25 \mathrm{mmol} / \mathrm{l})$ though $100 \mu \mathrm{mol} / \mathrm{l}$

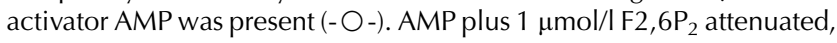
but did not effectively counteract the inhibition by citrate (-口-). In

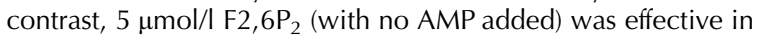
counteracting inhibition by citrate (-) - and this was reinforced by $500 \mu \mathrm{mol} / \mathrm{I}$ AMP (- $\boldsymbol{\Delta}$-) at citrate concentrations $\geq 2 \mathrm{mmol} / \mathrm{l}$. The assays were performed at $\mathrm{pH} 7.3$ with $4 \mathrm{mmol} / \mathrm{I} \mathrm{ATP}$ and $0.5 \mathrm{mmol} / \mathrm{I} \mathrm{F6P.}$ 


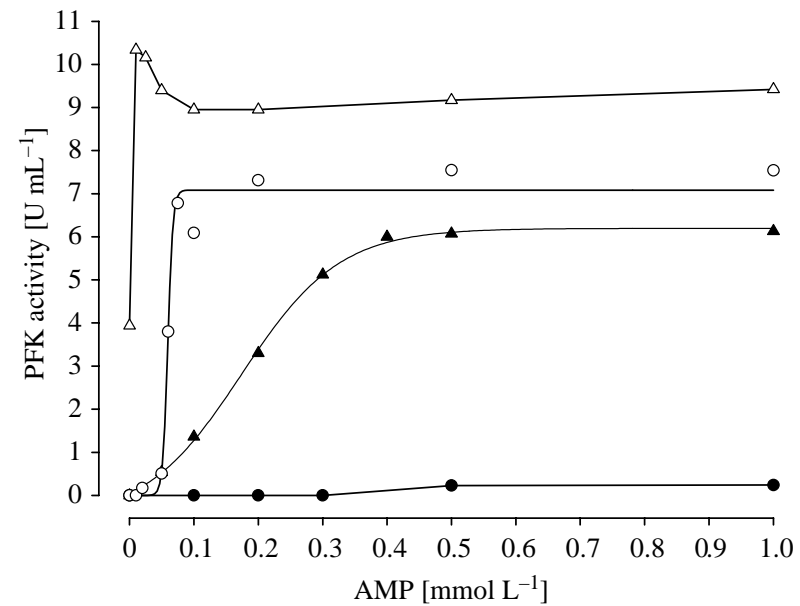

Figure 5 Effect of AMP on the activity of boar sperm PFK in dependence of citrate. In the absence of citrate, AMP is a potent activator of PFK (- $\bigcirc$-). Citrate at $0.5 \mathrm{mmol} / \mathrm{l}$ completely suppressed the activating effect of up to $1 \mathrm{mmol} / \mathrm{I}$ AMP (higher concentrations were not tested) (- - -). If $1 \mu \mathrm{mol} / / \mathrm{F} 2,6 \mathrm{P}_{2}$ was present in the assays, AMP retained its activating effect, though much higher concentrations were required for activation $(-\mathbf{\Delta}-)$, and the $V_{\max }$ was lower than that in the control with no citrate $(-\triangle$-). The assays were performed at $\mathrm{pH} 7.3$ with $4 \mathrm{mmol} / \mathrm{l}$ ATP and $0.5 \mathrm{mmol} / \mathrm{l} \mathrm{F6P.}$

citrate markedly inhibits sperm PFK, but $F 2,6 \mathrm{P}_{2}$ and $\mathrm{AMP}$ counteract with strong synergism this inhibition.

\section{pH and regulatory properties of boar sperm PFK}

Activity and regulatory properties of sperm PFK are strongly affected by $\mathrm{H}^{+}$concentration. At $2 \mathrm{mmol} / \mathrm{I} \mathrm{F6P}$ and $4 \mathrm{mmol} / \mathrm{l}$ ATP, boar sperm PFK reached maximum

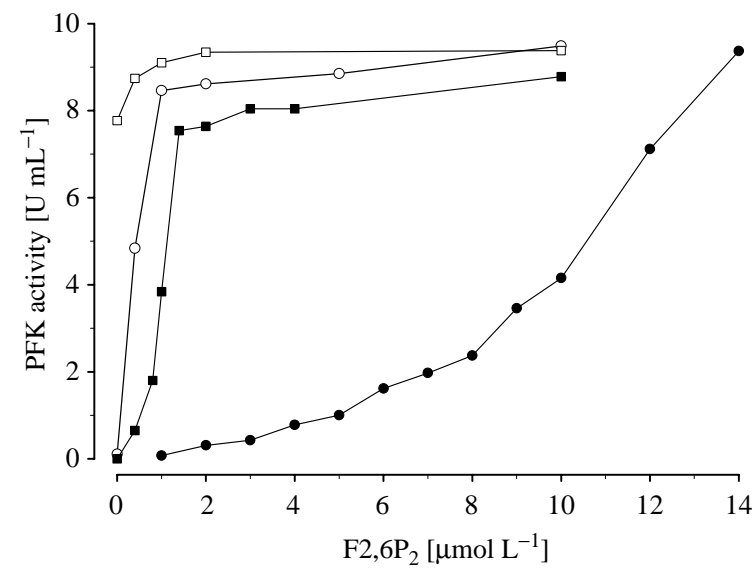

Figure 6 Effect of $F 2,6 \mathrm{P}_{2}$ on the activity of boar sperm PFK in the absence and the presence of citrate. In the absence of citrate, $F 2,6 \mathrm{P}_{2}$ was a potent activator of PFK (- $\left.\mathrm{O}_{-}\right)$and this effect was reinforced by $100 \mu \mathrm{mol} / \mathrm{l}$ AMP (- $\square$-). At $0.5 \mathrm{mmol} / \mathrm{l}$ citrate (with no AMP present), more than ten times higher concentrations of $\mathrm{F} 2,6 \mathrm{P}_{2}$ were required for $V_{\max }$ of PFK (- -) than in the absence of citrate. AMP (at $100 \mu \mathrm{mol} / \mathrm{l}$ ) synergistically reinforced activation of PFK by $\mathrm{F} 2,6 \mathrm{P}_{2}$ also in the presence of $0.5 \mathrm{mmol} / \mathrm{l}$ citrate (- $\mathbf{\square}-)$. The assays were performed at $\mathrm{pH}$ 7.3 with $4 \mathrm{mmol} / \mathrm{l}$ ATP and $0.5 \mathrm{mmol} / \mathrm{l} \mathrm{F6P.}$ activity at $\mathrm{pH} \geq 8.0$. At $\mathrm{pH}>8.0$, PFK had lost all its allosteric properties, i.e. PFK activity was modulated neither by inhibitors nor by activators (see Fig. 7). However, in the physiological $\mathrm{pH}$ range, PFK activity was sensitive to small changes in $\mathrm{pH}$ and varied greatly with substrate and effector concentrations. In the absence of activators, PFK was inactive below $\mathrm{pH} 7.0$ $\left(V_{\max }\right.$ at $\left.\mathrm{pH} 7.5\right)$. In the presence of $\mathrm{AMP}(100 \mu \mathrm{mol} / \mathrm{l})$, or AMP plus $\mathrm{F} 2,6 \mathrm{P}_{2}(1 \mu \mathrm{mol} / \mathrm{l}) \mathrm{PFK}$ was active at lower $\mathrm{pH}$ values. The $\mathrm{pH}$ values at which PFK was active were considerably higher if $0.5 \mathrm{mmol} / \mathrm{l}$ citrate was present in the assays. Thus, the effects of inhibitors and activators are reflected by shifting the $\mathrm{v} / \mathrm{pH}$-curves to higher or lower $\mathrm{pH}$ respectively.

At lower, more physiological substrate concentration $\left(0.5 \mathrm{mmol} / \mathrm{l} \mathrm{F6P)}\right.$ the inhibitory effects of $\mathrm{H}^{+}$on PFK activity were even more conspicuous than those at $2 \mathrm{mmol} / \mathrm{I} \mathrm{F6P}$ and resulted in very steep $\mathrm{v} / \mathrm{pH}$-curves (Fig. $8 \mathrm{a}-\mathrm{c}$ ). These $\mathrm{v} / \mathrm{pH}$-curves were typical in that, above critical $\mathrm{pH}$ values, relatively small increases in $\mathrm{pH}$, usually $\leq 0.3 \mathrm{pH}$ units, brought about the full activity of PFK. The critical $\mathrm{pH}$ values were dependent on the presence of activators and inhibitors of PFK. In the absence of effectors, PFK activity could not be detected below $\mathrm{pH}$ 7.6, but increased steeply at $\mathrm{pH}>7.6$ (Fig. 8a). In the presence of either $\mathrm{F} 2,6 \mathrm{P}_{2}$ (at $1 \mu \mathrm{mol} / \mathrm{l}$ ) or AMP (at $100 \mu \mathrm{mol} / \mathrm{l})$, PFK was activated at $\mathrm{pH} \geq 7.3$, with $V_{\max } / 2$ reached at about $\mathrm{pH} 7.5$ in both the cases. If both the activators were present, PFK was active above $\mathrm{pH}$ 6.8, reaching $V_{\max } / 2$ at about $\mathrm{pH} 7.0$ (see Fig. 8a).

Citrate shifted the $\mathrm{v} / \mathrm{pH}$-curves to markedly higher $\mathrm{pH}$ values (i.e. made PFK more sensitive to the inhibitor $\mathrm{H}^{+}$), but did not change the shape of the curves (see Fig. 8b). Thus, in the absence of activators, citrate (at $0.5 \mathrm{mmol} / \mathrm{l}$ ) completely blocked PFK activity below

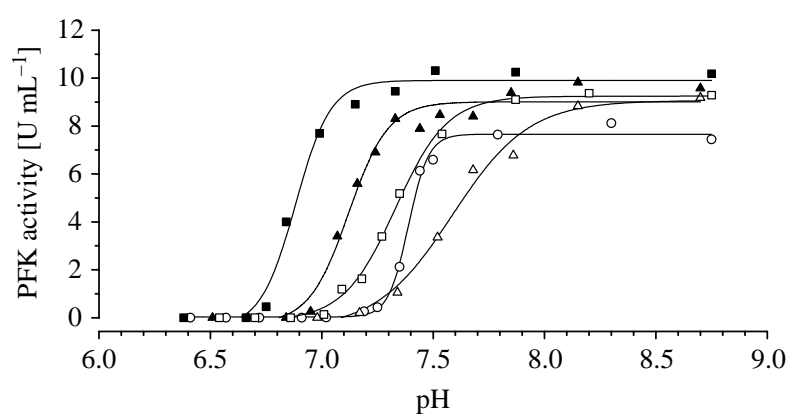

Figure 7 Effect of $\mathrm{pH}$ on the activity of boar sperm PFK at $2 \mathrm{mmol} / \mathrm{l} \mathrm{F6P}$ and $4 \mathrm{mmol} / \mathrm{I}$ ATP in the absence and the presence of various effectors. The effect of $\mathrm{pH}$ on PFK activity was greatly affected by the presence or the absence of effectors as is reflected by the $\mathrm{v} / \mathrm{pH}$-curves and the values of $\mathrm{pH}_{0.5}$, i.e. the $\mathrm{pH}$ at which $V_{\max } / 2$ was reached. AMP and $\mathrm{F} 2,6 \mathrm{P}_{2}$ shifted the curves to the left (i.e. to lower $\mathrm{pH}$ values), whereas citrate shifted them to higher $\mathrm{pH}$ values. In the absence of effectors, $V_{\max } / 2$ was at $\mathrm{pH} 7.4$ (-O-); with $100 \mu \mathrm{mol} / \mathrm{l} \mathrm{AMP}, V_{\max } / 2$ was at $\mathrm{pH}$ 7.15 (- $\mathbf{\Delta}$-); with $100 \mu \mathrm{mol} / \mathrm{l}$ AMP and $0.5 \mathrm{mmol} / \mathrm{l}$ citrate, $V_{\max } / 2$ was at $\mathrm{pH} 7.6\left(-\triangle\right.$-); with $100 \mu \mathrm{mol} / \mathrm{l}$ AMP plus $1 \mu \mathrm{mol} / / \mathrm{F} 2,6 \mathrm{P}_{2}$ (no citrate), $V_{\text {max }} / 2$ was at $\mathrm{pH} 6.9$ (-口-); with AMP plus $\mathrm{F} 2,6 \mathrm{P}_{2}$ and citrate (concentrations as before), $V_{\max } / 2$ was at $\mathrm{pH} 7.3$ (- $\square$-). 

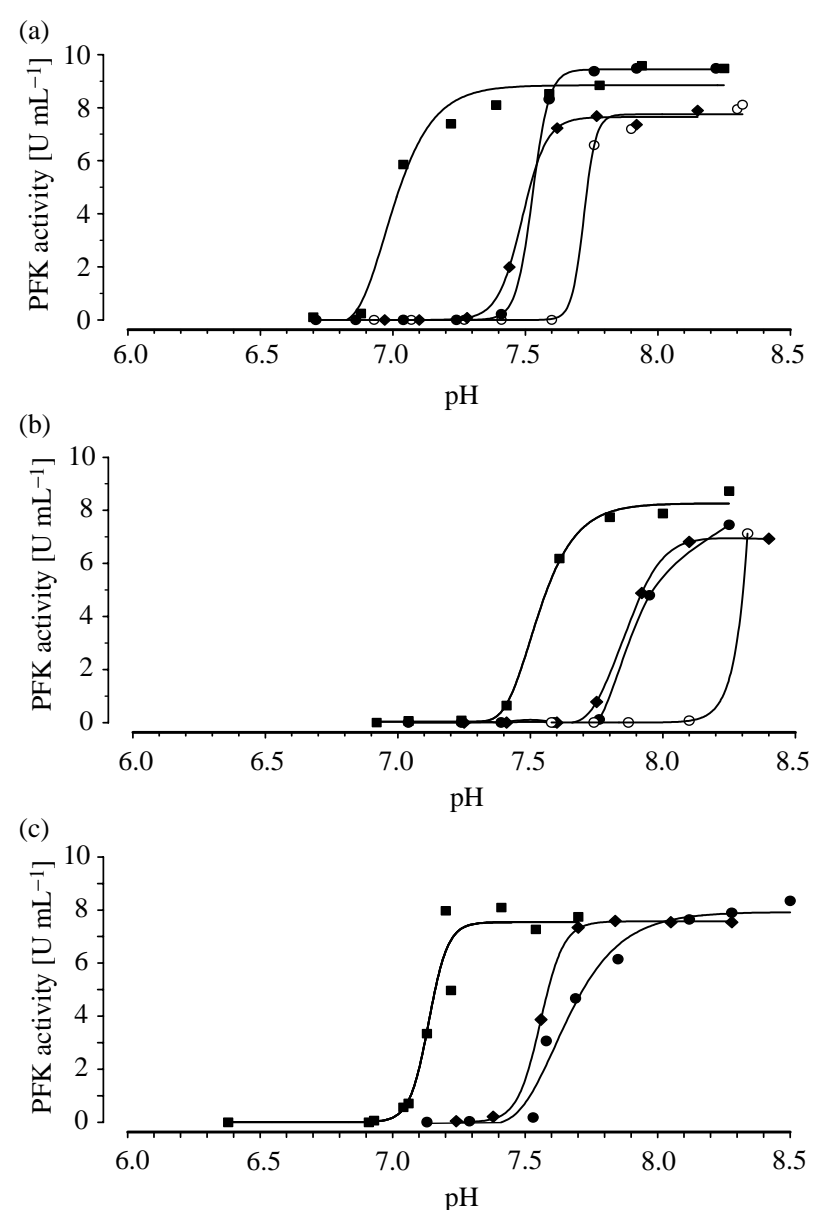

Figure 8 The effect of $\mathrm{pH}$ on the activity of boar sperm PFK (at $4 \mathrm{mmol} / \mathrm{l}$ ATP, $0.5 \mathrm{mmol} / \mathrm{F} 6 \mathrm{P}$ ) is strongly modulated by the activators AMP and $\mathrm{F} 2,6 \mathrm{P}_{2}$ and the inhibitor citrate. All v/pH-curves at this nearphysiological concentration of F6P were steep thus indicating that small changes in $\mathrm{pH}$ have marked effects on PFK activity. The $\mathrm{pH}$ values were adjusted as described in Materials and Methods and controlled again directly after the assays had been run. (a) No citrate added to the assays: In the absence of activators, $V_{\max } / 2$ was reached at about $\mathrm{pH} 7.7$ (-O-); at $100 \mu \mathrm{mol} / \mathrm{I}$ AMP, $V_{\max } / 2$ was at about $\mathrm{pH} 7.5$ (- -); at $1 \mu \mathrm{mol} / \mathrm{I} \mathrm{F} 2,6 \mathrm{P}_{2}, V_{\max } / 2$ was at $\leq \mathrm{pH} 7.5(--)$; with both AMP and $\mathrm{F} 2,6 \mathrm{P}_{2}$ present, $V_{\max } / 2$ was at about $\mathrm{pH} 7.0$ (-ם-). (b) Citrate at $0.5 \mathrm{mmol} / \mathrm{l}$ added to the assays, symbols as in (a). Citrate shifted the respective $\mathrm{v} / \mathrm{pH}$-curves to higher $\mathrm{pH}$ values by at least 0.3 units. With both AMP and $\mathrm{F} 2,6 \mathrm{P}_{2}$ present, citrate shifted the $\mathrm{pH}$ for $V_{\max } / 2$ by 0.5 units to $\mathrm{pH} 7.5$ (a pH which is probably not reached in sperm under physiological conditions; see Discussion). (c) Assays and symbols as in (b) (i.e. in the presence of $0.5 \mathrm{mmol} / \mathrm{l}$ citrate), but the concentrations of the activators were increased fivefold to $500 \mu \mathrm{mol} / \mathrm{IMP}$ and $5 \mu \mathrm{mol} / /$ $\mathrm{F} 2,6 \mathrm{P}_{2}$ respectively. This shifted the $\mathrm{v} / \mathrm{pH}$-curves to lower $\mathrm{pH}$ values by about 0.4 units with the effect that, in the presence of both AMP and $\mathrm{F} 2,6 \mathrm{P}_{2}, V_{\max } / 2$ was reached at about $\mathrm{pH} 7.1$.

$\mathrm{pH}$ 8.1. With either $\mathrm{F} 2,6 \mathrm{P}_{2}(1 \mu \mathrm{mol} / \mathrm{l})$ or AMP $(100 \mu \mathrm{mol} / \mathrm{l})$ present, PFK was activated at $\mathrm{pH} \geq 7.7$ (with $V_{\max } / 2$ at about $\mathrm{pH}$ 7.85). As before, $\mathrm{F} 2,6 \mathrm{P}_{2}$ and $\mathrm{AMP}$ acted synergistically in counteracting inhibition by $\mathrm{H}^{+}$, thus producing PFK activity at $\mathrm{pH} \geq 7.4$ (with $V_{\max } / 2$ at about $\mathrm{pH}$ 7.5). However, the combined activators did not activate PFK below pH 7.3 (Fig. 8b).
Increasing fivefold the concentrations of either activator, AMP or $\mathrm{F} 2,6 \mathrm{P}_{2}$, shifted the $\mathrm{v} / \mathrm{pH}$-curves to the left, but could not overcome the combined inhibiting effects of $\mathrm{H}^{+}$and citrate at $\mathrm{pH} \leq 7.4$. Yet again, with both activators present, sperm PFK was activated synergistically at $\mathrm{pH}>6.9$ to reach $V_{\max } / 2$ at about $\mathrm{pH}$ 7.1 (see Fig. 8c).

\section{Localization of PFK in boar sperm by immunogold labeling}

In western blots of extracts of boar spermatozoa, one band of protein cross-reacted with antibodies raised in goat against rabbit muscle PFK. The labeled band was at the same position as muscle PFK and was hence taken to represent sperm PFK (Fig. 9). The antibodies were therefore regarded suitable for localizing PFK in boar spermatozoa by immunogold labeling.

Electron micrographs of longitudinal sections of sperm head and of cross-sections through the mid-piece as well as through the flagellum and a cytoplasmic droplet show immunogold label in all these parts of spermatozoa (for details, see legend Fig. 10). As a control for immunological specificity, antibodies against PFK were eliminated by exposing them to purified rabbit muscle PFK. Sections of spermatozoa treated with this preincubated solution showed only few gold particles on sperm structures (for example Fig. 10g) but some were found on the matrix L R White.

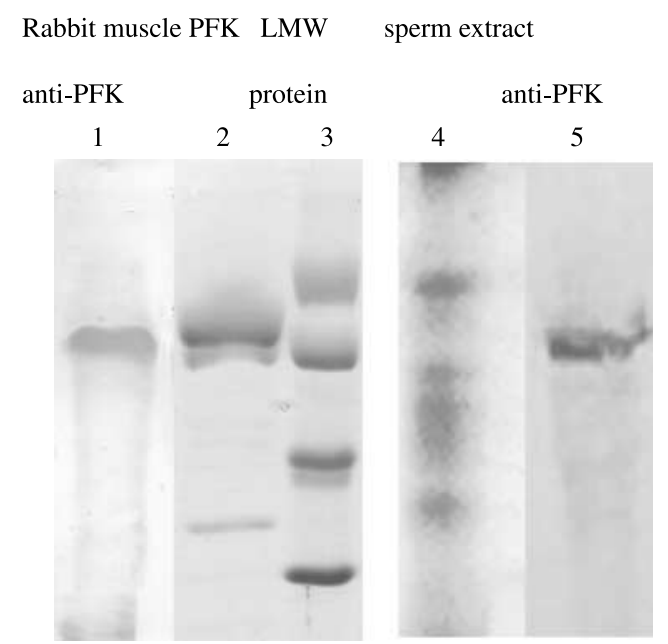

Figure 9 Electropherograms stained for protein (SDS-PAGE, lanes 2 and 4) and the corresponding western blots of PFK purified from rabbit skeletal muscle (lane 1) and of boar sperm extract (lane 5) treated with antibodies directed against PFK from rabbit muscle (see Materials and Methods). Lane 5 indicates that antibodies against muscle PFK recognize also PFK from boar spermatozoa, but no other sperm proteins (lane 4). Lane 3 shows standard proteins (low molecular weight), phosphorylase b (94 kDa), albumin (67 kDa), ovalbumin (43 kDa), carbonic anhydrase $(30 \mathrm{kDa})$, and trypsin inhibitor $(20 \mathrm{kDa})$ stained for protein. 

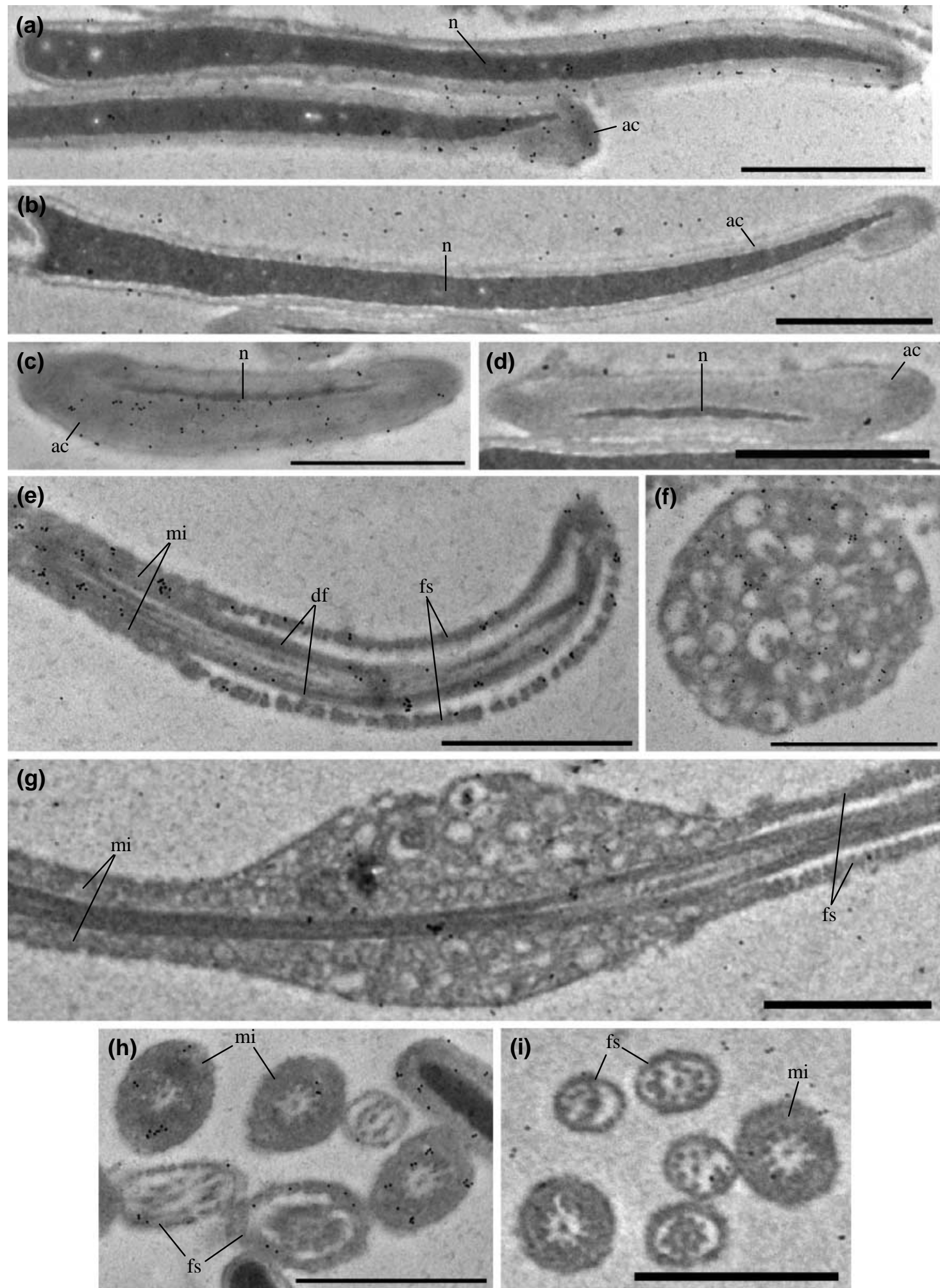

Figure 10 Immunogold staining of PFK in electronmicrographs of boar spermatozoa. Immunogold particles (10 nm) coupled to antibodies were used to localize PFK in boar spermatozoa (see Materials and Methods). Longitudinal sections (a) as well as a cross-section (c) through sperm heads show label mainly in the acrosome region. In controls ( $b$ and $d$ ) in which PFK antibodies were preabsorbed by muscle PFK, the acrosome region is free from label. In the flagellum, label is scattered over various structures in a longitudinal section showing parts of the mid-piece and the principal piece (e) as well as in cross-sections of both the compartments (h). In (f) a cytoplasmic droplet is labeled. In controls ( $\mathrm{g}$ and i) that had been treated with a solution of preabsorbed anti-PFK, no specific label is apparent (for details see text). ac, acrosome; df, dense fibers; fs, fibrous sheath; mi, mitochondria; $\mathrm{n}$, nucleus. 


\section{Discussion}

Spermatogenesis produces motile cells that have shed most if not all structures and capacities not necessary for motility and fertilization. In this process, spermatozoa have maturated to comparatively simple cells while gaining a high degree of compartmentation, and both properties make them apt models for studying the organization of energy metabolism. This holds particularly true for glycolysis, which appears to be a highly structured pathway in mammalian sperm. Major fractions of three glycolytic enzymes are tightly bound to the 'fibrous sheath', a sperm-specific cytoskeletal element of the principal piece of the flagellum. (1) The central enzyme glyceraldehyde 3-phosphate dehydrogenase (GAPDH, Westhoff \& Kamp 1997); (2) hexokinase at the beginning (Travis et al. 1998, 2001); and (3) pyruvate kinase (PK) at the end of glycolysis (Feiden, Stypa, Wegener, Wolfrum \& Kamp unpublished results). Complete extraction of these enzymes requires treating sperm with detergent or proteases. In contrast, PFK (like most other glycolytic enzymes) can be extracted with buffer after mechanical disruption of sperm. This had been reported earlier (Hoskins \& Stephens 1969, Harrison 1971, Jones \& Piccolo 1999) and is supported by our study. However, the relatively easy extraction does not rule out PFK being part of a highly organized metabolic superstructure ('metabolon' in the sense of Srere, see Robinson \& Srere 1986). There is evidence for such a glycolytic superstructure in boar sperm as GAPDH, which is anchored to the fibrous sheath via a sperm-specific elongation at the $\mathrm{N}$-terminus (Welch et al. 1992), interacts strongly with its two neighboring enzymes, TIM and phosphoglycerate kinase (Westhoff \& Kamp 1997). Specific interactions of PFK with cell structures or other enzymes have not yet been demonstrated in boar sperm, but such interactions have been observed on many other cell types, especially in muscle fibers where PFK is associated with actin filaments (for review see Knull \& Walsh 1992).

Using antibodies against PFK from rabbit muscle, we found label to be widespread throughout the flagellum (mid-piece and principal piece) and also in sperm head, especially in the acrosomal area. Hexokinase and lactate dehydrogenase are also present in the flagellum and sperm head. Using antibodies against rat brain hexokinase I, label was detected in the plasma membrane of the flagellum and the head (Visconti et al. 1996). Lactate dehydrogenase was visualized by a gel incubation film (Kohsaka et al. 1992). Immunofluorescence with spermspecific antibodies localized GAPDH and PK at the acrosome and the principal piece but not in the midpiece (Westhoff \& Kamp 1997, Feiden et al. unpublished results). These data suggest glycolytic activity not only in the flagellum, mainly in the principal piece, but also around the acrosome. But whether or not these enzymes are catalytically active and part of a complete glycolytic chain in the head of mature spermatozoa has not yet been established. If glycolysis is functioning in sperm heads, its activity might be related to the need of glycolytic ATP for cell signaling as proposed by Travis et al. (2001).

\section{Glycolysis in sperm is regulated and PFK is a major element of glycolytic control}

It has long been known that sperm increase glucose consumption and lactate production, i.e. glycolytic rate, with motility (Mounib \& Chang 1964, for review see Mann \& Lutwak-Mann 1981). Changes in the glycolytic rate in vivo are most likely driven by the different energy requirements that sperm must meet on their journey to fertilizing an egg (immotile in the epididymis, motile upon ejaculation, capacitated, and hyperactive in the female tract). So the question arose as to how glycolytic rate is regulated in spermatozoa.

Recent reports point to PFK as a single most important element of glycolytic control in sperm (Travis et al. 2001, Jones \& Connor 2004). Under physiological conditions, the PFK reaction is highly exergonic, i.e. the concentrations of substrates and products are maintained far removed from equilibrium. This is brought about by the strong inhibitory effects of physiological concentrations of ATP, citrate, and $\mathrm{H}^{+}$. Whenever glycolytic ATP is required, PFK must be de-inhibited (activated) by effectors like $\mathrm{AMP}, \mathrm{P}_{\mathrm{i}}$, or $\mathrm{F} 2,6 \mathrm{P}_{2}$.

\section{Regulatory properties of PFK from boar sperm}

PFK from boar sperm fits the general scheme of allosteric regulation of phosphofructokinases from various mammalian cell types in that it is a complex multimodulated enzyme. At physiological $\mathrm{pH}$, the enzyme is inhibited by physiological concentrations of its co-substrate ATP and by citrate. It is important to note that PFK loses allosteric inhibition, and with it all regulatory properties, at $\mathrm{pH}>8$, when the enzyme is fully active (see Figs 7 and 8 ). However, this is unlikely to happen in spermatozoa under physiological conditions. Boar spermatozoa studied in vitro by ${ }^{31} \mathrm{P}$ NMR and confocal microscopy showed an intracellular $\mathrm{pH}$ of 7.2 in the head and in the principal piece of the flagellum, whereas the mid-piece (containing the mitochondria) was more acidic (Kamp et al. 2003). The $\mathrm{pH}$ of ejaculated spermatozoa in vivo (i.e. in the female genital tract) is not known, but might be affected by the surrounding media (Gatti et al. 1993) or by sperm metabolism (Kamp et al. 2003). Yet, pH is certainly not the only factor affecting PFK activity in vivo. This notion seems not in line with a report by Jones \& Connor (2004), who did not find ATP or citrate to have any effect on PFK from boar spermatozoa. This is likely due to methodical problems since the authors apparently ran the assays at $\mathrm{pH} 8.0$, when allosteric effects are lost. 
Inhibition of boar sperm PFK by ATP and citrate can be attenuated by various activators, the most potent of which are AMP and F2,6 $\mathrm{P}_{2}$. However, as sole activator AMP is hardly effective at near-physiological substrate concentrations, especially if citrate is present. $\mathrm{F}_{2}, 6 \mathrm{P}_{2}$ is more effective, but relatively high concentrations are required. However, due to their strong synergism, both activators together are very efficient (see Figs 5 and 6). From our study, it would appear that both AMP and $\mathrm{F} 2,6 \mathrm{P}_{2}$ are crucial for activating (de-inhibiting) PFK in boar sperm. The activity of PFK could be enhanced by increasing both AMP and $\mathrm{F} 2,6 \mathrm{P}_{2}$, but because of their synergism increasing only one of the two would be sufficient as long as the other is present at a basal level. AMP has unambiguously been demonstrated in live boar spermatozoa by ${ }^{31} \mathrm{P}$ NMR in vivo (Kalic et al. 1997). Moreover, the concentration of AMP in boar sperm responds to environmental conditions. Thus, hypoxia increases AMP in live spermatozoa, but this can readily be reverted when oxygen is readmitted (Kamp et al. 2003). This is due to the fact that, unlike in vertebrate muscle (for review see, Krause \& Wegener 1996a, 1996c), AMP is not deaminated to IMP in boar sperm and also not dephosphorylated to adenosine (Kalic et al. 1997).

Changes in the content of $\mathrm{F} 2,6 \mathrm{P}_{2}$ in sperm have not yet been reported. In epididymal bull sperm, F2, $6 \mathrm{P}_{2}$ was estimated at $1-2 \mu \mathrm{mol} / \mathrm{l}$, but its concentration was not correlated with lactate production (Philippe et al. 1986). Measuring $\mathrm{F} 2,6 \mathrm{P}_{2}$ in ejaculated sperm is difficult because citrate in the seminal plasma interferes with the assay of $\mathrm{F} 2,6 \mathrm{P}_{2}$ (unpublished results). The concentration of $\mathrm{F}_{2}, 6 \mathrm{P}_{2}$ in ejaculated boar sperm, washed free of citrate, was estimated at $3.1 \pm 0.4 \mu \mathrm{mol} / \mathrm{l}$ (mean \pm S.E.M., $n=8$, unpublished results) assuming a cellular water space of $10^{-14}$ I per spermatozoon (Petrunkina \& Töpfer-Petersen 2000). In vertebrate skeletal muscle $\mathrm{F} 2,6 \mathrm{P}_{2}$ was shown to increase up to 40 -fold within seconds upon exercise (Wegener et al. 1990, for review see Wegener \& Krause 2002).

Inorganic phosphate $\left(\mathrm{P}_{\mathrm{i}}\right)$ is an activator of PFK, but large fractional changes in its concentration, as would be required for significant effects, have not been observed in boar spermatozoa (Kamp et al. 2003). However, they have been demonstrated in other spermatozoa (like those from sea urchins or carp, for review see Kamp et al. 1996) or in somatic cells (like skeletal muscles, for review Krause \& Wegener 1996c) that contain a phosphagen such as phosphocreatine. Boar spermatozoa lack a phosphagen (Kamp et al. 1996).

\section{How could PFK in sperm be switched on and off?}

Increasing glycolytic rate in sperm will require de-inhibition of PFK. The kinetics of PFK suggest that this could be achieved by increasing the concentrations of one or both of the activators AMP, F2,6 $\mathrm{P}_{2}$, possibly supported by an increase in $\mathrm{pH}$ when spermatozoa are released from the more acidic milieu of the epididymidis and diluted with the alkaline fluids of accessory glands (Rodriguez-Martinez et al. 1990). Increased motility is powered by an increased turnover of ATP and this will cause the concentration of ATP to decrease, while those of ADP and AMP will increase.

The situation is likely to resemble that in skeletal muscle going from rest to work, except that in muscle the breakdown of phosphagen buffers the ATP concentration and leads to a marked increase in $\mathrm{P}_{\mathrm{i}}$ in the initial phase of exercise. The changes in the adenylates ATP, ADP, and AMP in muscle in vivo have been studied using ${ }^{31} \mathrm{P} N M R$ and biochemical methods (for review see Krause \& Wegener 1996c, Wegener 1996, Wegener \& Krause 2002). With respect to our discussion, the most pertinent result of these studies was that a relatively small fractional decrease in ATP (e.g., by $10 \%$ ) will bring about a much larger fractional increase in free ADP (e.g., by $400 \%$ ), and this will cause free AMP to increase by more than $2600 \%$. These data apply to insect skeletal muscle (locust flight muscle) which, like boar sperm, accumulate AMP if ATP production does not meet ATP demand (as in hypoxia, Weyel \& Wegener 1996). In motile boar spermatozoa, AMP concentration can increase to $>1 \mathrm{mmol} / \mathrm{l}$ as shown by ${ }^{31} \mathrm{P}$ NMR spectroscopy if oxygen is limited (Kamp et al. 2003).

Decreasing glycolytic rate in sperm with reduced mechanical work load (for instance when spermatozoa attach themselves to the lining of the genital tract for rest, cf. Töpfer-Petersen et al. 2002) is readily conceivable given the regulatory properties of their PFK. Reduced ATP hydrolysis will cause the inhibitor ATP to increase, while the activators ADP and AMP will be decreased via the activity of AK. Moreover, if the activity of PFK were still higher than the actual flux through glycolysis, the PFK product $\mathrm{F} 1,6 \mathrm{P}_{2}$ would accumulate and reduce the efficacy of $F 2,6 P_{2}$ to activate PFK. This is due to the fact that $\mathrm{F} 1,6 \mathrm{P}_{2}$ competes with $\mathrm{F} 2,6 \mathrm{P}_{2}$ for the same regulatory site of $\mathrm{PFK}$, but induces a less active conformation than F2,6 $\mathrm{P}_{2}$ (see Tornheim 1985, Kemp \& Gunasekera 2002, Wegener \& Krause 2002). Of course, $F 2,6 \mathrm{P}_{2}$ in sperm could also be decreased with reduced work load, but this has not yet been demonstrated. However, substrate cycling between F6P and $\mathrm{F} 1,6 \mathrm{P}_{2}$ was reported in bovine spermatozoa (Hammerstedt \& Lardy 1983), and the second enzyme in this cycle (fructose-1,6-bisphosphatase) is present in epididymal bovine spermatozoa and strongly inhibited by $\mathrm{F}_{2}, 6 \mathrm{P}_{2}$ and AMP (Philippe et al. 1986). Moreover, fructose 1,6bisphosphatase is a key enzyme in gluconeogenetic tissues, and Mukai \& Okuno (2004) have recently suggested that mouse sperm might be able to produce glucose. However, this is unlikely in boar sperm where neither fructose 1,6-bisphosphatase nor gluconeogenesis could be demonstrated (Marin et al. 2003). 


\section{Open questions and perspectives}

The kinetics suggest that PFK activity is affected via an intracellular feedback loop by the adenylate system (in the sense of Atkinson's 1977, adenylate energy charge), and by factors that could reflect the extracellular milieus encountered by spermatozoa on their journey to fertilizing an egg. The effects of extracellular factors are hard to assess. Citrate may play a role, but despite its conspicuously high concentration in ejaculated semen, metabolic functions of seminal citrate are not known. Also not known are the concentrations of citrate in different compartments of sperm and how the extra- and intracellular citrate concentrations are related. Citrate is a mitochondrial substrate and a chelator with high affinities for divalent cations. Citrate could therefore support mitochondrial ATP production and/or attenuate the effects of $\mathrm{Ca}^{2+}, \mathrm{Mg}^{2+}, \mathrm{Zn}^{2+}$, or toxic metal ions. The effects of citrate in semen need to be studied. Recent experiments have shown that the concentration of citrate in the oviduct fluid of artificially inseminated sows is very low (Waberski, Wegener, Kamp, unpublished results). Furthermore, in preliminary experiments, the kinetics of washing ejaculated boar sperm in citrate-free media suggest that spermatozoa loose intracellular citrate in media low in citrate (unpublished results), which would indicate that citrate can permeate the plasma membrane of spermatozoa.

PFK from boar spermatozoa is very sensitive to changes in $\mathrm{pH}$, and this corresponds well with the effects of $\mathrm{pH}$ on glycolytic rate of boar spermatozoa in vitro (Jones \& Connor 2004). Unfortunately, how intracellular $\mathrm{pH}$ is controlled in different parts of spermatozoa in vivo is not known. However, it was recently demonstrated that the $\mathrm{pH}$ is low in the midpiece (probably due to mitochondrial activity) and higher in the principal piece of the sperm (Kamp et al. 2003), which would favor PFK activity where glycolysis is required for mechanical thrust.

$\mathrm{F} 2,6 \mathrm{P}_{2}$ is present in boar sperm (unpublished results), and the kinetics of PFK suggest that this activator is crucial for enzyme activity under near-physiological assay conditions. But it is not known whether the content of $\mathrm{F} 2,6 \mathrm{P}_{2}$ in ejaculated boar sperm changes with different conditions encountered by sperm before and during fertilization. The regulatory properties of PFK prompt detailed studies on the metabolism of $\mathrm{F} 2,6 \mathrm{P}_{2}$ in sperm as well as on the effects of extra- and intracellular citrate and $\mathrm{H}^{+}$on PFK activity in vivo.

\section{Acknowledgements}

Financial support from the Deutsche Forschungsgemeinschaft (Bonn) to G K and G W, as well as provision of boar semen by the breeders association GFS (Ascheberg) is gratefully acknowledged. We thank Dr D Harris (Oxford) for his comments on the manuscript and Dr U Knollmann for preparing the figures.

\section{References}

Almeida A, Moncada S \& Bolanos JP 2004 Nitric oxide switches on glycolysis through the AMP protein kinase and 6-phosphofructo-2kinase pathway. Nature Cell Biology 6 45-51.

Atkinson DE 1977 Cellular Energy Metabolism and its Regulation, New York, London: Academic Press, pp 293.

Bedford JM 1998 Mammalian fertilization misread? Sperm penetration of an eutherian zona pellucida is unlikely to be a lytic event. Biology of Reproduction 59 1275-1287.

Bone W, Jones NG, Kamp G, Yeung CH \& Cooper TG 2000 Effect of ornidazole on fertility of male rats: inhibition of glycolysis-related motility pattern and zona binding required for fertilization in vitro. Journal of Reproduction and Fertility 118 127-135.

Bunch D, Welch J, Magyar P, Eddy E \& O'Brien D 1998 Glyceraldehyde 3-phosphate dehydrogenase-S protein distribution during mouse spermatogenesis. Biology of Reproduction 58 834-841.

Fraser LR \& Quinn PJ 1981 A glycolytic product is obligatory for initiation of the sperm acrosome reaction and whiplash motility required for fertilization in the mouse. Journal of Reproduction and Fertility $6125-35$.

Gatti JL, Chevrier C, Paquignon M \& Dacheux JL 1993 External ionic conditions, internal $\mathrm{pH}$ and motility of ram and boar speermatozoa. Journal of Reproduction and Fertility 98 439-449.

Hammerstedt RH \& Lardy HA 1983 The effect of substrate cycling on the ATP yield of sperm glycolysis. Journal of Biological Chemistry 258 8759-8768.

Hanaichi T, Sato T, Iwamoto T, Malavasi-Yamashiro J, Hoshino M \& Mizuno N 1986 A stable lead by modification of Sato's method. Journal of Electron Microscopy 35 304-306.

Harrison RAP 1971 Glycolytic enzymes in mammalian spermatozoa. Activities and stabilities of hexokinase and phosphofructokinase in various fractions from sperm homogenates. Biochemical Journal 124 $741-750$.

Ho HC \& Suarez SS 2001 Hyperactivation og mammalian spermatozoa: function and regulation. Reproduction 122 519-526.

Hoskins DD \& Stephens DT 1969 Regulatory properties of primate sperm phosphofructokinase. Biochimica et Biophysica Acta 191 292-302.

Hue L \& Rider MH 1987 Role of fructose 2,6-bisphosphate in the control of glycolysis in mammalian tissues. Biochemical Journal 245 313-324.

Jones AR \& Connor DE 2004 Control of glycolysis in mature boar spermatozoa: effect of $\mathrm{pH}$ in vitro. Reproduction, Fertility, and Development 16 319-324.

Jones AR \& Piccolo F 1999 Glycolytic enzyme activity in hypotonically treated boar spermatozoa. Reproduction, Fertility, and Development 11 409-413.

Kalic M, Büsselmann G, Lauterwein J \& Kamp G 1997 Phosphorus metabolites in boar spermatozoa. Identification of AMP by multinuclear magnetic resonance. Biochimica et Biophysica Acta 1320 208-216.

Kamp G \& Lauterwein J 1995 Multinuclear magnetic resonance studies of boar seminal plasma. Biochimica et Biophysica Acta 1243 101-109.

Kamp G, Büsselmann G \& Lauterwein J 1996 Spermatozoa: models for studying regulatory aspects of energy metabolism. Experientia $\mathbf{5 2}$ 487-494.

Kamp G, Büsselmann G, Jones N, Wiesner B \& Lauterwein J 2003 Energy metabolism and intracellular $\mathrm{pH}$ in boar spermatozoa. Reproduction 126 517-525.

Kemp RG \& Foe LG 1983 Allosteric regulatory properties of muscle phosphofructokinase. Molecular and Cellular Biochemistry $\mathbf{5 7}$ 147-154.

Kemp RG \& Gunasekera D 2002 Evolution of the allosteric ligand sites of mammalian phosphofructo-1-kinase. Biochemistry $\mathbf{4 1}$ 9426-9430.

Knull HR \& Walsh JL 1992 Association of glycolytic enzymes with the cytoskeleton. Current Topics in Cellular Regulation 33 15-30. 
Kohsaka T, Takahara H, Tagami S, Sasada H \& Masaki J 1992 A new technique for the precise location of lactate and malate dehydrogenases in goat, boar and water buffalo spermatozoa using gel incubation film. Journal of Reproduction and Fertility 95 201-209.

Krause U \& Wegener G 1996a Exercise and recovery in frog muscle: metabolism of $\mathrm{PCr}$, adenine nucleotides, and related compounds. American Journal of Physiology 270 R811-R820.

Krause U \& Wegener G $1996 b$ Control of glycolysis in vertebrate skeletal muscle during exercise. American Journal of Physiology $\mathbf{2 7 0}$ R821-R829.

Krause U \& Wegener G 1996c Control of adenine nucleotide metabolism and glycolysis in vertebrate skeletal muscle during exercise. Experientia 52 396-403.

Kyhse-Andersen J 1984 Electroblotting of multiple gels: a simple apparatus without buffer tank for rapid transfer of proteins from polyacrylamide to nitrocellulose. Journal of Biochemical and Biophysical Methods 10 203-209.

Laemmli UK 1970 Cleavage of structural proteins during the assembly of the head of bacteriophage T4. Nature 227 680-685.

Mann T \& Lutwak-Mann C 1981 Male Reproductive Function and Semen: Themes and Trends in Physiology, Biochemistry and Investigative Andrology, Berlin, Heidelberg, New York: Springer-Verlag.

Marin S, Chiang K, Bassilian S, Lee WN, Boros LG, FernandezNovell JM, Centelles JJ, Medrano A, Rodriguez-Gil JE \& Cascante M 2003 Metabolic strategy of boar spermatozoa revealed by a metabolomic characterization. FEBS Letters 554 342-346.

Mentel T, Duch C, Stypa H, Wegener G, Müller U \& Pflüger HJ 2003 Central modulatory neurons control fuel selection in flight muscle of migratory locust. Journal of Neuroscience 23 1109-1113.

Mori C, Nakamura N, Welch J, Gotoh H, Goulding EH, Fujioka M \& Eddy E 1998 Mouse spermatogenic cell-specific type 1 hexokinase $(\mathrm{mHk} 1)$ transcripts are expressed by alternative splicing from the $\mathrm{mHk} 1$ gene and the HK 1 -S protein is localized mainly in the sperm tail. Molecular Reproduction and Development 49 374-385.

Mounib MS \& Chang MC 1964 Effect of in utero incubation on the metabolism of rabbit spermatozoa. Nature 201 943-944.

Mukai C \& Okuno M 2004 Glycolysis plays a major role for adenosine triphosphate supplementation in mouse sperm flagellar movement. Biology of Reproduction 71 540-547.

Nakamura M, Suzuki A, Okinaga S \& Arai K 1984 Stimulation of spermatid phosphofructokinase by fructose 2,6-bisphosphate from rat testes. Development, Growth and Differentiation 26 11-16.

Niwa K \& Iritani A 1978 Effect of various hexoses on sperm capacitation and penetration of rat eggs in vitro. Journal of Reproduction and Fertility 53 267-271.

Petrunkina AM \& Töpfer-Petersen E 2000 Heterogeneous osmotic behaviour in boar sperm populations and its relevance for detection of changes in plasma membrane. Reproduction, Fertility, and Development 12 297-305.

Philippe B, Rousseau GG \& Hue L 1986 Fructose 2,6-bisphosphate and the control of glycolysis in bovine spermatozoa. FEBS Letters 200 169-172.

Pilkis SJ 1990 Fructose 2,6-Bisphosphate, Boca Raton, FL: CRC Press.

Robinson JB Jr \& Srere PA 1986 Interaction of sequential metabolic enzymes of the mitochondria: a role in metabolic regulation. In Dynamics of Biochemical Systems, pp 159-171. Eds S Damjanovich, T Keleti \& L Trón. Budapest: Akadémiai Kiadó.
Rodriguez-Martinez H, Ekstedt E \& Einarsson S 1990 Acidification of epididymal fluid in the boar. International Journal of Andrology 13 238-243.

Töpfer-Petersen E, Wagner A, Friedrich J, Petrunkina AM, Waberski D \& Drommer W 2002 Function of the mammalian oviductal sperm reservoir. Journal of Experimental Zoology 292 210-215.

Tornheim K 1985 Activation of muscle phosphofructokinase by fructose 2,6-bisphosphate and fructose 1,6-bisphosphate is differently affected by other regulatory metabolites. Journal of Biological Chemistry $2607985-7989$.

Travis AJ, Foster JA, Rosenbaum NA, Visconti PE, Gerton GL, Kopf GS \& Moss SB 1998 Targeting of a germ cell-specific type 1 hexokinase lacking a porin-binding domain to the mitochondria as well as to the head and fibrous sheath of murine spermatozoa. Molecular Biology of the Cell 9 263-276.

Travis AJ, Jorgez CJ, Merdiushev T, Jones BH, Dess DM, Diaz-Cueto L, Storey BT, Kopf GS \& Moss SB 2001 Functional relationships between capacitation-dependent cell signaling and compartmentalized metabolic pathways in murine spermatozoa. Journal of Biological Chemistry 276 7630-7636.

Visconti PE, Olds-Clarke P, Moss SB, Kalab P, Travis AJ, de las Heras M \& Kopf GS 1996 Properties and localization of a tyrosine phosphorylated form of hexokinase in mouse sperm. Molecular Reproduction and Development 43 82-93.

Wegener G 1996 Flying insects: model systems in exercise physiology. Experientia 52 404-412.

Wegener G \& Krause U 2002 Different modes of activating phosphofructokinase, a key regulatory enzyme of glycolysis, in working vertebrate muscle. Biochemical Society Transactions $\mathbf{3 0}$ 264-270.

Wegener G, Beinhauer I, Kless A \& Newsholme EA 1987 Properties of locust muscle 6-phosphofructokinase and their importance in the regulation of glycolytic flux during prolonged flight. Journal of Comparative Physiology B 157 315-326.

Wegener G, Krause U \& Thuy M 1990 Fructose 2,6-bisphosphate and glycolytic flux in skeletal muscle of swimming frog. FEBS Letters $\mathbf{2 6 7}$ 257-260.

Welch J, Schatte EC, O'Brien D \& Eddy E 1992 Expression of a glyceraldehyde 3-phosphate dehydrogenase gene specific to mouse spermatogenic cells. Biology of Reproduction 46 869-878.

Westhoff D \& Kamp G 1997 Glyceraldehyde 3-phosphate dehydrogenase is bound to the fibrous sheath of mammalian spermatozoa. Journal of Cell Science 110 1821-1829.

Weyel W \& Wegener G 1996 Adenine nucleotide metabolism during anoxia and postanoxic recovery in insects. Experientia $\mathbf{5 2}$ 474-480.

Wolfrum U \& Schmitt A 2000 Rhodopsin transport in the membrane of the connecting cilium of mammalian photoreceptor cells. Cell Motility and the Cytoskeleton 46 95-107.

Received 27 June 2006

First decision 7 August 2006

Accepted 15 August 2006 